Prosiding Seminar Nasional Teknologi Informasi dan Kedirgantaraan : Peran Teknologi untuk Revitalisasi Bandara dan Transportasi Udara, Yogyakarta, 10 Desember 2019

SENATIK 2019, Vol. V, ISBN 978-602-52742-1-3

DOI: $10.28989 /$ senatik.v5i0.311

\title{
CONCEPTUAL DESIGN OF ELECTRICAL DUCTED FAN (EDF)
}

\author{
Buyung Junaidin ${ }^{1)}$, M. Ardi Cahyono ${ }^{2)}$ \\ Departemen Teknik Dirgantara, Sekolah Tinggi Teknologi Adisutjipto \\ Jl. Janti Blok R Lanud Adisutjipto Yogyakarta

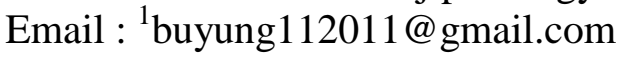

\begin{abstract}
Electric Ducted Fan (EDF) is an electric propulsion consist of duct, fan and electric motor with main power source is from battery which generates compression air for thrust. EDF is used as an alternative propulsion for high speed UAV especially for target UAV or "bomb" controlled UAV. It's design is very simple and no need extra maintenance compared to jet engine. Design process of an EDF is more simple than a jet engine, nevertheless it could obtain enough thrust for high speed flying. The aim of this research is to design an EDF as an alternative propulsion for high speed UAV and performance analyzing of EDF using analitical approach. Design of EDF produce an EDF with inlet and outlet diameter are $70 \mathrm{~mm}$ and $60 \mathrm{~mm}$. Total length of EDF is $116,1 \mathrm{~mm}$. Performance analysis of EDF shows that by $700 \mathrm{~W}$ of motor power could reach $16 \mathrm{~N}$ of thrust which is accepted performace for $70 \mathrm{~mm}$ $E D F$.
\end{abstract}

Keywords: Design, Electric Ducted Fan (EDF).

\section{Pendahuluan}

Perkembangan pesawat udara tanpa awak atau unmanned aerial vehicle (UAV) yang sangat pesat menghasilkan berbagai macam jenis, ukuran maupun karakter UAV. Salah satu yang berkembang adalah high-speed UAV. Jenis ini memiliki kecepatan tinggi di atas ratarata UAV biasanya dan biasa digunakan sebagai target udara dalam latihan militer atau digunakan sebagai alternatif "bom" kendali jarak jauh. High-speed UAV mengharuskan penggunaan propulsi dengan gaya dorong besar sehingga pesawat mampu mencapai kecepatan tinggi. Untuk memenuhi kebutuhan itu, maka propulsi jet sangat cocok diaplikasikan untuk high-speed UAV. Akan tetapi, penggunaan jet engine membutuhkan biaya yang cukup besar, baik dalam hal produksi dan pengembangan maupun operasionalnya. Selain itu, sistem jet engine yang komplek membutuhkan perawatan ekstra sehingga aklan menambah biaya yang dibutuhkan. Sebagai alternatifnya, penggunaan propulsi elektrik sangat membantu dalam mengurangi biaya produksi dan operasional. Bentuk propulsi elektrik yang yang dimaksud adalah electric ducted fan (EDF). Electric Ducted Fan (EDF) merupakan propulsi elektrik yang terdiri dari duct, fan dan motor electrik dengan sumber tenaga motor berasal dari baterai sehingga dapat mengasilkan udara terkompresi yang menghasilkan gaya dorong.

Perancangan dan konfigurasi EDF lebih sederhana dibandingkan dengan jet engine, namun dapat menghasilkan gaya dorong yang cukup untuk kebutuhan terbang cepat seperti pada high-speed UAV. Perbedaan utama antara EDF dengan motor-propeler biasa adalah terletak pada penggunaan duct sebagai penambah kecepatan aliran dan fan yang menghasilkan kompresi udara lebih besar, sehingga dapat menghasilkan gaya dorong yang lebih besar dibandingkan dengan motor-propeler biasanya dengan spesifikasi motor dan ukuran diameter rotor yang sama. Penelitian tentang perancangan EDF sebagai alternatif sistem propulsi untuk UAV masih sangat sedikit dipublikasikan sehingga informasi dan referensi dalam melakukan penelitian yang sama masih sangat minim. Hal ini dikarenakan EDF telah menjadi benda komersil yang memiliki paten bagi perancangnya sehingga tidak 
semua informasi mengenai proses perancangan EDF dipublikasikan. Alternatif yang bisa digunakan sebagai informasi adalah artikel tentang ducted fan dan penelitian tentang perancangan duct sebagai pengarah aliran udara. Pada tahun 2013, Sharman R.A. dan Cheng menulis artikel dengan judul Electric Ducted Fan - theory and practice yang menjelaskan bagaimana proses perancangan dan analisis EDF dengan prinsip konservasi massa. Dalam artikel tersebut tidak dijelaskan bagaimana cara merancang bentuk difuser dan fan dari EDF. Pada tahun 2005, Pereira dan Chopra melakukan penelitian pengaruh bentuk diffuser duct terhadap nilai thrust yang dihasilkan. Dari hasil penelitian mereka diperoleh konfigurasi diffuser duct yang optimal.

Penelitan tentang duct lebih banyak fokus pada perancangan duct sebagai pengarah aliran dari putaran propeler, sangat sedikit yang melakukan penelitian khusus tentang EDF sebagai alternatif sistem propulsi UAV. Fokus dari penelitian ini adalah melakukan perancangan EDF sebagai alternatif propulsi pesawat UAV dan melakukan analisis performa EDF dengan pendekatan analitik.

\section{Metodologi Penelitian}

Metode perancangan duct dari EDF dalam penelitian ini menggunakan prinsip konservasi massa [1] dengan asumsi - asumsi yang dilibatkan antara lain: aliran udara dianggap tidak terkompresi (incompressible flow) karena perubahan temperatur udara tidak signifikan, gesekan pada permukaan duct dianggap tidak ada (frictionless duct), bentuk penampang potong duct adalah lingkaran mengikuti bentuk fan serta ukuran efektif EDF berdasarkan luas sapuan fan dari EDF.

Anaisis performa EDF menggunakan prinsip konservasi massa dengan asumsi asumsi yang libatkan antara lain: aliran udara dianggap tidak terkompresi (incompressible flow), gesekan pada permukaan duct dianggap tidak ada (frictionless duct), bentuk penampang potong duct adalah lingkaran serta ukuran efektif EDF berdasarkan luas sapuan fan dari EDF.

Prinsisp konservasi massa menyatakan bahwa laju aliran massa udara yang melewati duct adalah konstan sesuai persamaan 2.1.

$$
\left(\dot{Q}_{i}=\rho A_{i} v_{i}\right)=\left(\dot{Q}_{o}=\rho A_{o} v_{o}\right), \text { dimana } \rho=\text { constant }
$$

Kecepatan aliran udara di outlet dapat dihitung dengan persamaan 2.2.

$$
v_{o}=\frac{A_{i}}{A_{o}} v_{o}
$$

Thrust yang dihasilkan oleh duct dikarenakan adanya perubahan momentum dari massa udara yang bergerak, dapat dihitung dengan persamaan 2.3.

$$
T=M \Delta v, \text { dimana } \Delta v=v_{o}-v_{i}
$$

Daya yang dibutuhkan dari EDF untuk terbang dapat dihitung dengan persamaan 2.4.

$$
P_{\text {flight }}=T v_{i}
$$

Daya yang dihasilkan EDF karena adanya aliran masuk merupakan energi kinetik dari massa udara yang masuk, dihitung dengan persamaan 2.5.

$$
P_{\text {gain }}=1 / 2 M v_{i}^{2}
$$

Sedangkan daya yang hilang akibat aliran udara yang meninggalkan EDF, dapat dihitung dengan persamaan 2.6.

$$
P_{\text {loss }}=1 / 2 M v_{o}^{2}
$$

Daya yang dihasilkan fan dar EDF dapat dihitung dengan persamaan 2.7. 


$$
P_{\text {fan }}=P_{\text {loss }}-P_{\text {gain }}
$$

Nilai efisiensi fan dan motor EDF dapat dihitung dengan persamaan 2.8a dan 2.8b.

$$
\begin{aligned}
& \eta_{\text {fan }}=P_{\text {flight }} / P_{\text {fan }}(\text { biasanya sekitar } 80 \%) \\
& \left.\eta_{\text {motor }}=P_{\text {fan }} / P_{\text {motor }} \quad \text { (biasanya sekitar } 85 \%\right)
\end{aligned}
$$

Analisis performa EDF meliputi analisis thrust statis dan dinamik dari EDF serta perbandingan daya yang dibutuhkan dengan daya yang dihasilkan EDF. Selain itu, rujukan penelitian sebelumnya [2] digunakan untuk menentukan konfigurasi diffuser dari duct sesuai gambar 1. Menurut Pereira \& Chopra konfigurasi optimal untuk duct adalah blade tip clearance $\left(\delta_{\text {tip }}\right)=0,1 \% \mathrm{D}_{\mathrm{t}}$, radius inlet lip $\left(\mathrm{r}_{\text {lip }}\right)=13 \% \mathrm{D}_{\mathrm{t}}$, sudut difuser $\left(\theta_{\mathrm{d}}\right)=10^{\circ}$ dan panjang difuser $\left(\mathrm{L}_{\mathrm{d}}\right)=50 \%-72 \% \mathrm{D}_{\mathrm{t}}$. Konfigurasi ini menghasilkan thrust $90 \%$ lebih tinggi untuk propeler dibandingkan tanpa menggunakan duct.

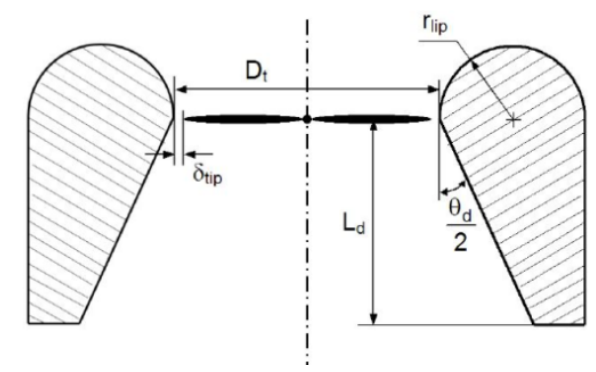

Gambar 1. Parameter difuser.

(Sumber Pereira \& Chopra, 2005)

\section{Hasil dan Pembahasan}

Proses perancangan EDF dimulai dengan penentuan diameter inlet duct yang ditetapkan $70 \mathrm{~mm}$ sama dengan diameter duct pabrikan yang telah ada sebelumnya dengan katagori mini EDF berdasarkan klasifikasi ukuran salah satu pabrikan EDF (Wemotec), sedangkan diameter outlet duct adalah $60 \mathrm{~mm}[3,4]$. Diameter dalam dan panjang tempat motor masing-masing $35 \mathrm{~mm}$ dan $60 \mathrm{~mm}$. Geometri difuser EDF diperoleh berdasarkan referensi [2] antara lain: blade tip clearance $\left(\delta_{\text {tip }}\right)=1 \mathrm{~mm}$ (pembulatan darai $0,7 \mathrm{~mm}$ untuk keperluan manufaktur), radius inlet lip $\left(\mathrm{r}_{\text {lip }}\right)=9,1 \mathrm{~mm}$, sudut difuser $\left(\theta_{\mathrm{d}}\right)=10^{\circ}$ dan panjang difuser $\left(\mathrm{L}_{\mathrm{d}}\right)=27 \mathrm{~mm}$. Dari hasil perhitungan panjang EDF tanpa fan cone dan motor cone adalah 96,1mm, dengan asumsi panjang fan cone dan motor cone masing-masing $10 \mathrm{~cm}$, sehingga total panjang EDF 116,1 mm. Geometri EDF yang telah diperoleh selanjutnya dibuat model tiga dimensi menggunakan bantuan software CAD. Model tiga dimensi EDF hasil perancangan sesuai gambar 2 .

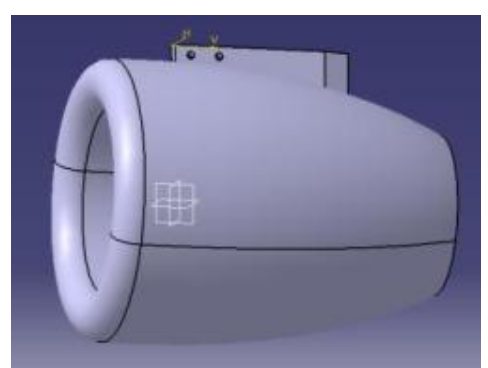

Gambar 2. Model 3D EDF hasil perancangan 
Performa EDF dianalisis dengan pendekatan analitik dan prinsip konservasi massa. Hasil perhitungan performa EDF meliputi thrust pada kondisi statis dan dinamik serta daya yang dihasilkan.

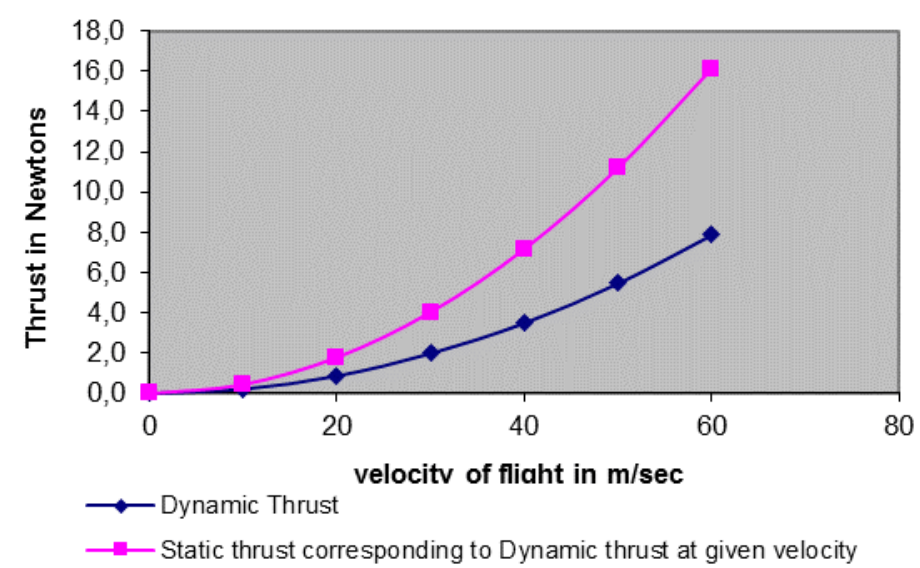

Gambar 3. Hasil perhitungan nilai thrust EDF

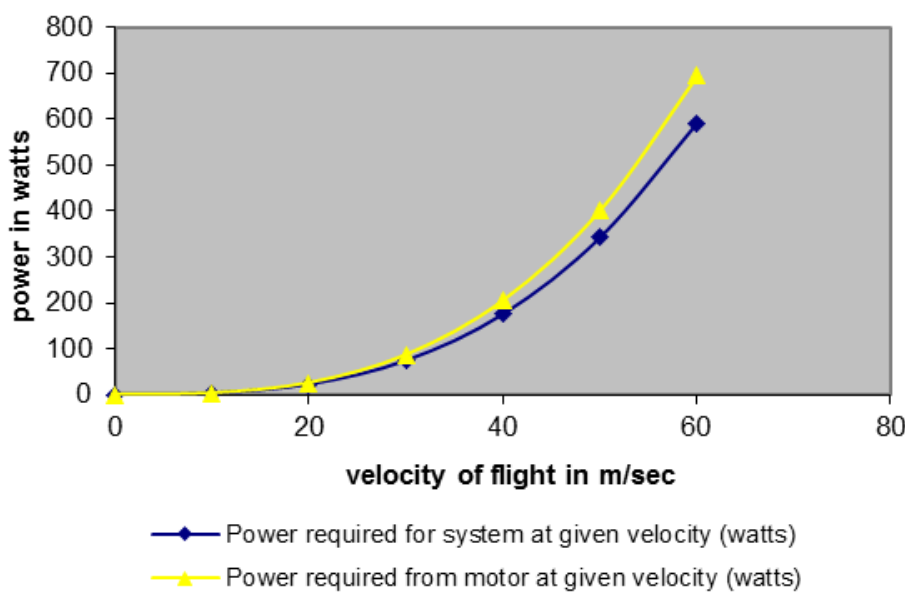

Gambar 4. Hasil perhitungan daya EDF

Pada gambar 3, thrust statis diperoleh dari perhitungan dengan asumsi bahwa EDF pada kondisi diam, sedangkan thrust dinamik dihitung dengan asumsi EDF bergerak bersama pesawat UAV. Hasil perhitungan menunjukkan nilai thrust statis lebih besar dari thrust dinamik, hal ini dikarenakan thrust dihitung berdasarkan perubahan momentum dari aliran udara yang dipengaruhi perubahan kecepatan aliran udara. Pada kondisi statis, pertambahan kecepatan aliran udara lebih besar dibandingkan kondisi dinamik, sehingga menghasilkan thrust lebih besar. Untuk ukuran mini EDF, nilai thrust yang dihasilkan sudah di dalam batas antara $2-17 \mathrm{~N}$ atau biasanya sekitar 6,8N [3]. Rekomendasi daya untuk motor EDF berdiameter 70mm adalah 700-1000W. Pada gambar 4 dan gambar 3, dengan daya motor $700 \mathrm{~W}$ mampu menghasilkan thrust statis sebesar $16 \mathrm{~N}$.

\section{Kesimpulan}

Hasil penelitian diperoleh rancangan EDF dan performa hasil analisis. Dari hasil perancangan dihasilkan konfigurasi EDF dengan diameter inlet $70 \mathrm{~mm}$ dan diameter outlet 
$60 \mathrm{~mm}$ serta total panjang EDF adalah $116,1 \mathrm{~mm}$. EDF menggunakan fan dan motor elektrik dengan diameter maksimal masing-masing $68 \mathrm{~mm}$ dan $35 \mathrm{~mm}$. Hasil analisis performa EDF menunjukkan bahwa EDF memenuhi syarat performa untuk EDF 70mm, sehingga dapat disimpulkan perancangan EDF dinyatakan berhasil dan memenuhi syarat secara performa.

\section{Ucapan Terimakasih}

Ucapan terimakasih kami sampaikan kepada lembaga Penelitian dan Pengabdian Masyarakat Sekolah Tinggi Teknologi Adisutjipto yang telah membiayai penelitian ini.

\section{Daftar Pustaka}

[1] Sharman R.A. \& Cheng (2013). Electric Ducted Fan - theory and practice

[2] Pereira \& Chopra. (2005, January). Effects of shroud design variables on hover performance of a shrouded-rotor for micro air vehicle applications, AHS International Specialists' Meeting on Unmanned Rotorcraft, Chandle, AZ.

[3] Understanding Ducted Fans http://www.rcflyg.se/forum/attachment.php?attachmentid=47384\&d=1409248095 Diakses 4 Juli 2015.

[4] Basics of Electric Ducted Fans https://www.wattflyer.com/forums/attachment.php?attachmentid=47263\&d=119541099 $\underline{0}$ Diakses 4 Juli 2015. 
Buyung Junaidin, M. Ardi Cahyono

PST-8 